\title{
Chemical Composition of Mycoplasma Cells and Membranes
}

\author{
By S. RAZIN, M. ARGAMAN and J. AVIGAN \\ Department of Clinical Microbiology and Department of Biochemistry, \\ Hebrew University-Hadassah Medical School, \\ Jerusalem, Israel
}

(Received 12 August 1963)

\begin{abstract}
SUMMARY
The chemical composition of whole organisms and cell membranes of eight saprophytic and parasitic Mycoplasma strains was studied. Cell membranes of $\boldsymbol{M}$. laidlarwi and $\boldsymbol{M}$. bovigenitalium were prepared by osmotic shock. The membranes comprised about $35 \%$ of the dry weight of the organisms. Generally the solid residue of the mycoplasmas contained 54-62 \% protein, 12-20\% lipid, 3-8\% carbohydrate, $8-17 \%$ RNA and 4-7 \% DNA. Cell membranes contained 47-60\% protein, 35-37\% lipid, 4-7\% carbohydrate, and small amounts of RNA and DNA which could not be washed away with de-ionized water. The saprophytic $M$. laidlawii contained only one-fourth to one-third of the total cholesterol found in the lipid of the parasitic strains. No cholesterol was detected in M. laidlawii grown in cholesterol-free media. Acetone-insoluble lipids formed the major part of the lipid in the saprophytic strains, and the minor part in the lipid of the parasitic strains. The carotenoid pigments of $M$. laidlawii were retained in the cell membrane preparations.
\end{abstract}

\section{INTRODUCTION}

The Mycoplasma organisms are the smallest organisms which are capable of autonomous growth. The study of their biochemistry is therefore of special interest, and a prerequisite for the use of these minute organisms as models for testing current theories about protein, DNA and RNA interrelationships (Morowitz \& Cleverdon, 1959, 1960; Morowitz et al. 1962). Information about the chemical composition of mycoplasmas may help in the elucidation of their much disputed phylogenetic status and might form the basis for immunochemical studies. The few chemical studies so far carried out have been confined to certain cell constituents, a complete chemical analysis being available for only one strain of Mycoplasma gallisepticum (Morowitz et al. 1962). A partial analysis of the chemical components of a Mycoplasma strain isolated from man was reported by Lynn \& Smith (1960). These reports do not reveal any essential difference between the chemical composition of the Mycoplasma strains tested and of bacteria in general, except for the presence of cholesterol in the mycoplasmas. Trace amounts of sterols have been found only in very few bacterial species (Fiertel \& Klein, 1959).

Mycoplasma organisms are limited by a thin membrane, which resembles the plasma membrane of bacteria, and are devoid of cell walls (Razin, 1963). Consequently, mycoplasmas do not contain the specific cell-wall substances muramic acid and diaminopimelic acid (Kandler \& Zehender, 1957; Plackett, 1959; Razin \& 
Argaman, 1961). In thin sections of Mycoplasma organisms the membrane seems to be composed of two electron-dense layers with a less dense layer in between (Van Iterson \& Ruys, 1960). This three-layered structure corresponds to the 'unit membrane' which covers cells and organelles of various origins (Robertson, 1959; Burgen, 1962). Preliminary studies of Mycoplasma cell membranes have indicated their lipoprotein nature (Razin, 1963). The electrical properties of the cell membranes of $M$. gallisepticum have been studied by Schwan \& Morowitz (1962). The marked sensitivity of several Mycoplasma strains to lysis by osmotic shock (Razin, 1964) has enabled the isolation of sufficient quantities of mycoplasma membranes for their chemical analysis which is now reported.

\section{METHODS}

Organisms. Mycoplasma laidlawü strain A (PG8), M. laidlawii strain B (PG 9), M. bovigenitalium ( $\mathrm{PG} 11$ ), M. mycoides var. mycoides ( $\mathrm{PG} 1$ ) and M. neurolyticum (PG 28) were obtained from Dr D. G. ff. Edward (Wellcome Research Laboratories, Beckenham, Kent, England). M. mycoides var. capri was the gift of Dr E. Klieneberger-Nobel (The Lister Institute for Preventive Medicine, London). A strain culturally and biochemically resembling $M$. laidlawii was isolated from the oral cavity of a healthy subject (Razin, Michmann \& Shimshoni, 1964); this is referred to here as the oral strain. M. gallisepticum was obtained from Mrs Ruth Bernstein (Faculty of Agriculture, The Hebrew University, Rehovoth, Israel).

Cultivation and harvesting of organisms. The growth medium was a modified liquid Edward medium (Razin, 1964) containing $2 \%(\mathrm{v} / \mathrm{v})$ Bacto-PPLO serum fraction and $0.5 \%(\mathrm{w} / \mathrm{v})$ glucose. Five-litre Erlenmeyer flasks containing 2-3 1 . medium were inoculated with $10 \mathrm{ml}$./l. of a $24-48 \mathrm{hr}$. culture grown in the same medium. The flasks were incubated statically at $37^{\circ}$ for $24-48 \mathrm{hr}$. and the organisms collected in a Sharples Super-centrifuge. The paste of organisms obtained was resuspended in $0.25 \mathrm{M}-\mathrm{NaCl}$ solution and centrifuged at $20,000 \mathrm{~g}$ for $5 \mathrm{~min}$. The sedimented organisms were then washed twice with the $\mathrm{NaCl}$ solution and freezedried.

Isolation of cell membranes. Cell membranes of Mycoplasma laidlawii and $\boldsymbol{M}$. bovigenitalium were prepared by osmotic lysis of the organisms (Razin, 1964). The salinewashed packed organisms (1-2 g. wet weight) were suspended in de-ionized water (about $300 \mathrm{ml}$.) and centrifuged at $20,000 \mathrm{~g}$ for $5 \mathrm{~min}$. The opalescent viscous supernatant fluid was separated and the sediment resuspended in de-ionized water and centrifuged at $20,000 \mathrm{~g}$ for $5 \mathrm{~min}$. This time only a minute amount of sediment was formed; this was discarded. The supernatant fluids were pooled and centrifuged at $30,000 \mathrm{~g}$ for $40 \mathrm{~min}$. The sediment was washed four times in de-ionized water and freeze-dried. Samples of the washed sediment were suspended in de-ionized water, placed on grids covered with collodion films, and fixed by $\mathrm{OsO}_{4}$ vapour for $15 \mathrm{~min}$. The specimens were shadowed with a gold palladium alloy at an angle of $15^{\circ}$, and examined with an RCA EMU 3c electron microscope.

Analytical methods. Lipids were extracted from freeze-dried organisms or membranes by a chloroform + methanol mixture $(2+1$, by vol. $)$. Extraction was at $60^{\circ}$ under reflux for $1 \mathrm{hr}$. in a nitrogen atmosphere. The extract was separated, filtered through sintered glass and washed with water according to Folch, Lees \& Sloane- 
Stanley (1957). The solvent was then evaporated under a stream of nitrogen, and the lipid residue freeze-dried and weighed. Acetone fractionation of the lipid was done by a modification of the method described by Al-Doory \& Larsh (1962). Cold acetone was added to the dried lipid and the mixture left at $4^{\circ}$ overnight. The supernatant fluid was then separated by centrifugation and a fresh portion of acetone was added to the precipitate. After incubation for $1 \mathrm{hr}$. at room temperature the supernatant fluid was separated and added to the first supernatant fluid; the acetone was evaporated under a stream of nitrogen and the residue freeze-dried and weighed, as was the acetone-insoluble precipitate. Total phosphorus in the lipid fractions was determined as described by Umbreit, Burris \& Stauffer (1957).

Cholesterol and cholesterol esters were determined by thin-layer chromatography (Avigan, Goodman \& Steinberg, 1963). Plates about $250 \mu$ thick and pre-stained with Rhodamine $6 \mathrm{G}$ were prepared with the Desaga applicator (Desaga; Heidelberg, Germany) by plating a slurry containing $55 \mathrm{ml}$. of $0.1 \%$ aqueous solution of the dye and 25 g. silica gel G (E. Merck, A. G., Darmstadt, Germany). The lipid to be chromatographed was dissolved in benzene and applied on plates as bands containing up to $5 \mathrm{mg}$. of material. The developing solvent was a mixture of benzene + ethyl acetate $(5+1$; by vol.) and the running time was about $90 \mathrm{~min}$. Sterol zones were visible, after chromatography, under ultraviolet radiation as pink-yellow fluorescent areas on a pale background. For recovery the zones were scraped off with a spatula and transferred to a filter paper, and the sterol eluted with chloroform. This chloroform was evaporated under a stream of nitrogen and the dry material was dissolved in glacial acetic acid. The amount of cholesterol in solution was determined by the $\mathrm{FeCl}_{3}$ reaction (Wycoff \& Parsons, 1957).

The amount of lipid retained by the organisms after chloroform + methanol extraction was estimated according to Ikawa (1963). The lipid-extracted organisms were refluxed in $2 \mathrm{~N}-\mathrm{HCl}$ overnight, and the hydrolysate was treated with ether. The ether was evaporated under nitrogen, and the residue dissolved in chloroform. The solution was then washed with an equal volume of water, the washed chloroform extract was evaporated to dryness under nitrogen, and the residue weighed.

Protein, carbohydrate and nucleic acids were determined in defatted organisms. Protein was estimated according to Lowry, Rosebrough, Farr \& Randall (1951). Extraction of protein was effected by boiling the organisms in $0 \cdot 1 \mathrm{~N}-\mathrm{NaOH}$ for $10 \mathrm{~min}$. Total carbohydrate was estimated according to Dubois et al. (1956), with glucose as standard. Nucleic acids were extracted according to Schneider (1945). RNA was determined by the method of Drury (1948) and DNA according to Burton (1956).

\section{RESULTS}

\section{Chemical composition of organisms}

Table 1 summarizes the results of the chemical analysis of eight Mycoplasma strains. Each result represents the average of 5-10 determinations performed on different batches of organisms. Generally, there was no great variation in the chemical composition of the organisms of different strains except that most parasitic strains had a somewhat higher lipid content than the saprophytic strains, and that the Mycoplasma gallisepticum organisms contained a smaller amount of total carbohydrates. 
Table 1. Chemical composition of Mycoplasma organisms

$\overbrace{\text { Mean }{ }_{\text {Range }}}^{\text {Protein }} \overbrace{\text { Mean }}^{\text {Lipid }} \overbrace{\text { Range }}^{\text {Carbohydrate }} \overbrace{\begin{array}{c}\text { Mean Range } \\ \% \text { dry wt. }\end{array}}^{\text {RNA }} \overbrace{\text { Range }}^{\text {DNA }} \overbrace{\text { Mean Range }}^{\text {Rean }}$

Organism

Mycoplasma laidlawii strain A

M. laidlawii strain B

M. laidlawii, oral strain

M. mycoides var. capri

M. mycoides var. mycoides

M. bovigenitalium

M. neurolyticum

M. gallisepticum

\begin{tabular}{|c|c|c|c|c|c|c|c|c|c|}
\hline $55 \cdot 2$ & $48 \cdot 1-65 \cdot 0$ & $12 \cdot 8$ & $10 \cdot 0-14 \cdot 8$ & $7 \cdot 1$ & $5 \cdot 1-9 \cdot 3$ & $14 \cdot 2$ & $8 \cdot 6-18 \cdot 0$ & $7 \cdot 2$ & $4 \cdot 4-7 \cdot 9$ \\
\hline $54 \cdot 4$ & $47 \cdot 3-62 \cdot 1$ & $12 \cdot 1$ & $9 \cdot 8-16 \cdot 2$ & $7 \cdot 4$ & $6 \cdot 5-7 \cdot 5$ & $12 \cdot 0$ & $10 \cdot 5-14 \cdot 1$ & $5 \cdot 1$ & $4 \cdot 2-6 \cdot 2$ \\
\hline $55 \cdot 8$ & $48 \cdot 0-60 \cdot 8$ & $13 \cdot 2$ & $11 \cdot 1-17 \cdot 6$ & $6 \cdot 9$ & $5 \cdot 2-8 \cdot 0$ & $14 \cdot 4$ & $13 \cdot 2-16.7$ & $6 \cdot 3$ & $4 \cdot 2-7 \cdot 0$ \\
\hline $58 \cdot 2$ & $50 \cdot 7-62 \cdot 4$ & $11 \cdot 9$ & $8 \cdot 8-12 \cdot 8$ & $6 \cdot 5$ & $4 \cdot 9-8 \cdot 1$ & $17 \cdot 3$ & $13 \cdot 5-22 \cdot 0$ & $5 \cdot 0$ & $3 \cdot 2-7 \cdot 7$ \\
\hline $54 \cdot 0$ & $46 \cdot 9-58 \cdot 3$ & $17 \cdot 2$ & $16 \cdot 6-20 \cdot 3$ & $8 \cdot 1$ & $7 \cdot 0-10 \cdot 2$ & $11 \cdot 4$ & $9 \cdot 5-13 \cdot 7$ & $6 \cdot 1$ & $4 \cdot 2-7 \cdot 6$ \\
\hline $58 \cdot 5$ & $52 \cdot 0-65 \cdot 7$ & $16 \cdot 4$ & $12 \cdot 0-21 \cdot 4$ & $7 \cdot 2$ & $5 \cdot 2-9 \cdot 4$ & $12 \cdot 9$ & $8 \cdot 2-16 \cdot 1$ & $5 \cdot 3$ & $4 \cdot 4-8 \cdot 2$ \\
\hline $57 \cdot 1$ & $46 \cdot 3-62 \cdot 1$ & $20 \cdot 3$ & $18 \cdot 1-22 \cdot 5$ & 6.0 & $4.5-6.5$ & $13 \cdot 2$ & $10 \cdot 4-14 \cdot 0$ & $4 \cdot 0$ & $3 \cdot 5-5 \cdot 2$ \\
\hline $62 \cdot 7$ & $55 \cdot 3-67 \cdot 9$ & $15 \cdot 7$ & $12 \cdot 2-20 \cdot 6$ & $2 \cdot 9$ & $2 \cdot 6-3 \cdot 7$ & $8 \cdot 3$ & $6 \cdot 1-8 \cdot 7$ & $4 \cdot 1$ & $3 \cdot 5-5 \cdot 0$ \\
\hline
\end{tabular}

Table 2. Acetone-insoluble fraction and cholesterol content of the lipid of

Mycoplasma organisms

Acetone-insoluble fraction Total cholesterol

Organism

Mycoplasma laidlazii

strain A

M. laidlawii strain B

$M$. laidlareii oral strain

M. mycoides var. capri

M. mycoides var. mycoides

$\overbrace{\text { Mean Range }} \overbrace{\text { Mean Range }}^{\text {Tean Ral }}$

$\%(w / w)$ total lipid

$\boldsymbol{M}$. bovigenitalium

M. neurolyticum

$\boldsymbol{M}$. gallisepticum

\begin{tabular}{|c|c|c|c|}
\hline $72 \cdot 8$ & $70 \cdot 3-75 \cdot 4$ & $7 \cdot 0$ & $4.5-10 \cdot 2$ \\
\hline $75 \cdot 4$ & $71 \cdot 0-80 \cdot 1$ & $8 \cdot 2$ & $6 \cdot 5-10 \cdot 5$ \\
\hline $70 \cdot 4$ & $66 \cdot 7-73 \cdot 2$ & $7 \cdot 7$ & $4 \cdot 5-11 \cdot 0$ \\
\hline $35 \cdot 5$ & $22 \cdot 8-53 \cdot 7$ & $\mathbf{2 8} \cdot \mathbf{4}$ & $19 \cdot 0-34 \cdot 5$ \\
\hline $35 \cdot 8$ & $33 \cdot 0-40 \cdot 9$ & $30 \cdot 8$ & $20 \cdot 1-32 \cdot 5$ \\
\hline $45 \cdot 3$ & $32 \cdot 1-60 \cdot 3$ & $27 \cdot 9$ & $16 \cdot 2-30 \cdot 5$ \\
\hline $30 \cdot 9$ & $30 \cdot 2-32 \cdot 5$ & $26 \cdot 2$ & $18 \cdot 1-29 \cdot 9$ \\
\hline $50 \cdot 3$ & $50 \cdot 0-52 \cdot 7$ & $20 \cdot 1$ & $13 \cdot 1-24 \cdot 3$ \\
\hline
\end{tabular}


Chloroform + methanol ( $2+1$, by vol.) extracted almost all the lipid from the mycoplasma organisms; only negligible amounts of additional lipid were recovered from extracted organisms after hydrolysis with $2 \mathrm{~N}-\mathrm{HCl}$. The amount of lipids extracted from the organisms by methanol + ether (Gilby, Few \& McQuillen, 1958) was about the same as that obtained with chloroform + methanol. A partial analysis of the lipid component of the various mycoplasmas is given in Table 2 . The acetoneinsoluble fraction, containing 3-4\% phosphorus, apparently consists of phospholipids. The lipid of the saprophytic strains contained a much higher percentage of acetone-insoluble fraction than that of the parasitic strains. On the other hand, the amount of cholesterol and its esters, found exclusively in the acetone-soluble fraction, was three to four times higher in the parasitic mycoplasmas than in the saprophytic organisms. The appearance of cholesterol in Mycoplasma laidlawii depended on its presence in the growth medium (Table 3). Thus, appreciable amounts of cholesterol were found in organisms grown in Edward medium enriched with human serum or Bacto-PPLO serum fraction (which is known to contain cholesterol; Edward, 1953; Smith, Lecce \& Lynn, 1954). On the other hand, no cholesterol was detected by the methods used in $M$. laidlawii grown in Edward medium without serum or serum fraction, or in a cholesterol-free defined medium (Razin \& Cohen, 1963; Razin \& Rottem, 1964). The organisms grown in the defined medium were also deficient in carotenoid pigments, which are characteristic of $M$. laidlawii. The amounts of protein, lipid, carbohydrate and nucleic acids were, however, the same as in organisms grown in Edward medium.

Table 3. Cholesterol content of Mycoplasma laidlawii (oral strain) grown in different media

Growth medium

Edward medium $+15 \%(v / v)$ human serum

Edward medium $+2 \%(v / v)$ Bacto-PPLO

serum fraction

Edward medium without serum or serum

fraction

Defined medium (Razin \& Cohen, 1963)
$\%$ of total cholesterol by weight of total lipid

$10 \cdot 5$

$11 \cdot 0$

$<0.25 *$

$<0 \cdot 25 *$

* This figure represents the limit of sensitivity of the method used.

\section{Chemical composition of cell membranes}

The amount of membrane material obtained from the three Mycoplasma laidlawii strains represented $32-36 \%$ of the dry weight of organisms. The chemical composition of the cell membranes of $M$. laidlawii and $M$. bovigenitalium is given in Table 4 . The membranes contained about three times more lipid than did the whole organisms. All membrane preparations contained small amounts of RNA and DNA. Several washings of the membranes with de-ionized water decreased the amount of nucleic acids but did not remove them completely. Table 5 summarizes the results of a partial analysis of the membrane lipids. Like intact organisms, the amount of cholesterol in the membranes of the parasitic $\boldsymbol{M}$. bovigenitalium was much higher than in membranes of $M$. laidlawii. Virtually all the carotenoid pigments of $M$. laidlawii were retained in the membrane preparations. 
Table 4. Chemical composition of Mycoplasma cell membranes

\begin{tabular}{|c|c|c|c|c|c|c|c|c|c|}
\hline \multicolumn{2}{|c|}{ Protein } & \multicolumn{2}{|c|}{ Lipid } & \multicolumn{2}{|c|}{ Carbohydrate } & \multicolumn{2}{|c|}{ RNA } & \multicolumn{2}{|c|}{ DNA } \\
\hline Mean & Range & Mean & Range & Mean & Range & Mean & Range & Mean & Range \\
\hline \multicolumn{10}{|c|}{$\%$ dry weight } \\
\hline $47 \cdot 3$ & $46 \cdot 0-52 \cdot 2$ & $36 \cdot 0$ & $30 \cdot 1-38 \cdot 3$ & $6 \cdot 0$ & $3 \cdot 9-7 \cdot 8$ & $2 \cdot 8$ & $2 \cdot 1-3 \cdot 4$ & $0 \cdot 9$ & $0 \cdot 15-2 \cdot 2$ \\
\hline $57 \cdot 1$ & $45 \cdot 6-60 \cdot 1$ & $35 \cdot 6$ & $25 \cdot 8-40 \cdot 1$ & $4 \cdot 4$ & $3 \cdot 1-6 \cdot 1$ & $\mathbf{3} \cdot \mathbf{0}$ & $1 \cdot 2-3 \cdot 9$ & $1 \cdot 1$ & $0 \cdot 75-2 \cdot 2$ \\
\hline $49 \cdot 8$ & $48 \cdot 0-51 \cdot 2$ & $34 \cdot 9$ & $32 \cdot 0-38 \cdot 5$ & $6 \cdot 2$ & $3 \cdot 7-9 \cdot 0$ & $\mathbf{2 \cdot 9}$ & $2 \cdot 7-4 \cdot 2$ & $\mathbf{1} \cdot \mathbf{1}$ & $1 \cdot 0-2 \cdot 0$ \\
\hline $59 \cdot 2$ & $57 \cdot 6-60 \cdot 3$ & $37 \cdot 3$ & $32 \cdot 5-38 \cdot 9$ & $6 \cdot 8$ & $4 \cdot 4-10 \cdot 0$ & $\mathbf{2} \cdot 0$ & $1 \cdot 1-2 \cdot 3$ & $0 \cdot 8$ & $0 \cdot 7-1 \cdot 4$ \\
\hline
\end{tabular}

Table 5. Acetone-insoluble fraction and cholesterol content of the lipid

able 5. Acetone-insoluble fraction and cholesterol
of Mycoplasma cell membranes

lawi $i$ strain

$M$. laidlazwii strain $\mathbf{B}$

M. laidlawii oral strain

M. bovigenitalium

\begin{tabular}{|c|c|c|c|c|}
\hline & \multicolumn{2}{|c|}{ Acetone-insoluble fraction } & \multicolumn{2}{|c|}{ Total cholesterol } \\
\hline & Mean & Range & Mean & Range \\
\hline & \multicolumn{4}{|c|}{$\%(w / w)$ total lipid } \\
\hline $\begin{array}{l}\text { Mycoplasma laidlawii } \\
\text { strain A }\end{array}$ & $45 \cdot 3$ & $41 \cdot 5-53 \cdot 6$ & $\mathbf{5 \cdot 3}$ & $3 \cdot 7-6 \cdot 0$ \\
\hline M. laidlareii strain $\mathrm{B}$ & $52 \cdot 4$ & $40 \cdot 8-62 \cdot 7$ & $8 \cdot 1$ & $45-12 \cdot 2$ \\
\hline M. laidlazeii oral strain & 44.7 & $41 \cdot 0-48 \cdot 9$ & $6 \cdot 2$ & $4 \cdot 6-7 \cdot 3$ \\
\hline M. bovigenitalium & $40 \cdot 3$ & $37 \cdot 0-58 \cdot 7$ & $18 \cdot 4$ & $14 \cdot 3-25 \cdot 2$ \\
\hline
\end{tabular}




\section{DISCUSSION}

In general the chemical composition of the Mycoplasma strains tested does not vary much from that of other bacteria. The mycoplasmas are rich in lipids, as previously reported by Smith \& Rothblat (1962). The amount of lipid in mycoplasma organisms varied between 10 and $20 \%$ of the total dry weight; most bacteria contain 1-10\% of lipid (O'Leary, 1962). The high lipid content of mycoplasmas may be due to the lipid-rich membrane in these minute organisms, constituting more than one-third of the total cell mass. Similarly, bacterial L-forms have been found to contain a much higher percentage of lipids than do their parent bacteria (Vendrely \& Tulasne, 1953; Smith \& Rothblat, 1962). The minute bacterium Dialister pneumosintes also contains about $22 \%$ of lipid (Chen \& Cleverdon, 1962). The extraction of lipids from Mycoplasma organisms appears to be easier than from eubacteria. The chloroform + methanol mixture extracted practically all the lipid from mycoplasmas, but only some of the lipid from several eubacteria, the remainder being extracted only after acid hydrolysis (Ikawa, 1963). This difference may possibly be due to the absence of cell walls from Mycoplasma organisms. The relatively thick cell walls of eubacteria may interfere with the extraction of lipids from these organisms, as it has been shown that a thorough grinding of streptococci markedly improved lipid extraction with chloroform + methanol (MacLeod \& Brown, 1963). The same solvent mixture removed about $90 \%$ of the lipid of plasma membranes of streptococci without any previous treatment (Freimer, 1963).

Analysis of the lipid extracted from the mycoplasmas showed that the saprophytic strains contained mostly acetone-insoluble lipids, while the parasitic strains contained more acetone-soluble lipids. This can be accounted for by the much higher amounts of acetone-soluble cholesterol in the parasitic strains. The lower cholesterol content of the saprophytic mycoplasmas, which contain carotenoid pigments in the cell membrane, is of particular interest. It is a reasonable speculation that the carotenoids occupy the same sites in the membranes of the saprophytic mycoplasmas as does cholesterol in the membranes of parasitic strains (see Rothblat \& Smith, 1961 ; Lucy \& Dingle, 1962). The carotenoids may thus diminish cholesterol uptake by the saprophytic strains. The present results conform to the findings of Smith \& Rothblat $(1960,1962)$ and Rothblat \& Smith (1961), that the cholesterol found in Mycoplasma laidlawii originates in the growth medium. The acetoneinsoluble lipid of mycoplasmas consists largely of phospholipids which have not yet been characterized. Preliminary analysis indicates the presence of lecithin in this fraction. Lecithin, cephalins, inositides and glycerophosphatidic acid were found in M. gallisepticum (Morowitz et al. 1962), and glycerophosphatidic acid was identified in M. mycoides var. mycoides (Plackett, 1961). Phospholipids which possess a nitrogenous base, such as choline, have been found in the lipid fraction of protoplast membranes of streptococei (Freimer, 1963). The protoplast membranes of Micrococcus lysodeikticus (Gilby et al. 1958; MacFarlane, 1961), Bacillus megaterium (Weibull \& Bergström, 1958; Yudkin, 1962) and Streptococcus faecalis (Shockman et al. 1963) essentially contained no other phospholipids except glycerophosphatidic acid.

The amount of total carbohydrate was similar in the various Mycoplasma strains tested, except for Mycoplasma gallisepticum which contained significantly lower 
amounts. Morowitz et al. (1962) found very small amounts of carbohydrates in a strain of $M$. gallisepticum. Analysis of the carbohydrate component has not yet been carried out. A galactan comprising about $10 \%$ of the dry weight of $M$. mycoides var. mycoides was described by Buttery \& Plackett (1960).

The results obtained in the present study and those reported by Morowitz et al. (1962) show that the percentage of nucleic acids in the total dry weight of mycoplasma organisms does not differ significantly from that found in other bacteria. Lynn \& Smith (1957, 1960) claimed that a Mycoplasma strain isolated from man contained much lower amounts of nucleic acids than is generally found in bacteria; the low (5-6\% of dry wt. of organism) nucleic acids content found by Lynn \& Smith may be characteristic of their strain, or was due to a leakage of nucleic acid from osmotically-fragile organisms caused during washing (see Panos, Barkulis \& Hayashi, 1959).

The membranes which we isolated from Mycoplasma laidlawii and $M$. bovigenitalium comprised about $35 \%$ of the total dry weight of organisms, whereas bacterial protoplast membranes represented only 6.7\% (Shockman et al. 1963) to $20 \%$ (Weibull \& Bergström, 1958) of the dry weight of the bacteria. The reason for the difference apparently lies in the much smaller dimensions of Mycoplasma organisms and their lack of cell wall. Both these factors tend to increase the relative proportion of cell membrane in the total cell mass. Smith \& Rothblat (1962) disrupted Mycoplasma organisms by sonic vibration and found about one-half of the dry weight of their organisms in the sedimentable material, which apparently consisted mostly of cell membrane.

Lipid constitutes about $\mathbf{3 5} \%$ of the dry weight of the Mycoplasma membranes we tested; this is a higher percentage than is recorded for bacterial protoplast membranes which contain 15-30\% lipid (Gilby et al. 1958; Weibull \& Bergström, 1958; Mitchell, 1959; Yudkin, 1962; Shockman et al. 1963; Freimer, 1963). Calculation shows that almost all the lipid of Mycoplasma organisms is located in the membrane. Bacterial protoplast membranes contain more than $80 \%$ of the total cell lipid (MacFarlane, 1961). Almost all the cell cholesterol and carotenoids were found in the membranes of Mycoplasma laidlawii (see Rothblat \& Smith, 1961). The possible functions of cholesterol and carotenoids as stabilizers of membrane structure have already been discussed (Rothblat \& Smith, 1961; Smith \& Rothblat, 1962; Razin, 1963, 1964). According to Rothblat \& Smith (1961), cholesterol and carotenoids may also play a part in the transport of metabolic substrates and end-products across the cell membrane. Cholesterol, which is adsorbed from the growth medium, is apparently incorporated into the membrane, and forms an integral part of it, as indicated by the marked sensitivity of mycoplasmas to lysis by digitonin (Smith \& Rothblat, 1960; Razin \& Argaman, 1963).

The presence of small amounts of RNA and DNA in the Mycoplasma membrane preparations was to be expected. Small amounts of nucleic acids have always been associated with isolated membranes of bacterial protoplasts or 'oxidosomes' of cells (Weibull \& Bergström, 1958; Weibull, Beckman \& Bergström 1959; Suit, 1962; De Ley, 1962 ; Hughes, 1962 ; Markovitz \& Dorfman,1962 ; Hutner \& Godson, 1962 ; Shockman et al. 1963; Freimer, 1963). It is difficult to decide whether the residual nucleic acids we found were contaminants or true membrane components. It has been shown that ribosomes may be firmly attached to biological membranes and may be the active 
sites for the biosynthesis of new membranes (De Ley, 1962; Hutner \& Godson, 1962). Small electron-dense granules, possibly ribosomes, have been observed adhering to isolated Mycoplasma membranes (Fig. 1 in Razin, 1963). Treatment of isolated streptococcal protoplast membranes with crystalline RNase and DNase removed the electron-dense granules associated with freshly-isolated membranes (Freimer, 1963).

Our thanks are due to Mrs E. Friedberg and Mr M. Wormser for their valuable technical assistance. This work was supported in part by a grant from the Joint Research Fund of the Hebrew University-Hadassah Medical School.

\section{REFERENCES}

AL-Doory, Y. \& LARsh, H. W. (1962). Quantitative studies of total lipids of pathogenic fungi. Appl. Microbiol. 10, 492.

Avigan, J., Goodman, D. S. \& Steinberg, D. (1963). 'Thin-layer chromatography of sterols and steroids. J. Lipid Res. 4, 100.

Burgen, A. S. V. (1962). The structure and function of cell membranes. Canad. J. Biochem. Physiol. 40, 1253.

Burton, K. (1956). A study of the conditions and mechanism of the diphenylamine reaction for the colorimetric estimation of deoxyribonucleic acid. Biochem. J. 62, 315.

Buttery, S. H. \& Plackett, P. (1960). A specific polysaccharide from Mycoplasma mycoides. J. gen. Microbiol. 23, 357.

Chen, C. C. \& Cleverdon, R. C. (1962). The chemical composition of Dialister pneumosintes and the significance of the studies of small eubacteria. Life Sciences, 1, 401.

De LEY, J. (1962). The separation of ribosomes and oxidosomes from bacteria. Biochem. $J$. 84, 9 P.

DruRY, H. F. (1948). Identification and estimation of pentoses in the presence of glucose. Arch. Biochem. 19, 455.

Dubois, M., Gilles, K., Hamilton, K., Rebas, P. \& Smith, E. (1956). Determination of carbohydrates by phenol. Anal. Chem. 28, 350.

EDWARD, D. G. ff. (1953). A difference in growth requirements between bacteria in the L-phase and organisms of the pleuro-pneumonia group. J.gen. Microbiol. 8, 256.

Fiertel, A. \& Klein, H. P. (1959). On sterols in bacteria. J. Bact. 78, 738.

Folch, J., Lees, M. \& Sloane-Stanley, G. H. (1957). A simple method for the isolation and purification of total lipids from animal tissues. J. biol. Chem. 226, 497 .

Freimer, E. H. (1963) Studies of L forms and protoplasts of group A streptococci II. Chemical and immunological properties of the cell membrane. J. exp. Med. 117, 377.

Gilby, A. R., Few, A. V. \& McQuillen, K. (1958). The chemical composition of the protoplast membrane of Micrococcus lysodeikticus. Biochim. biophys. Acta, $29,21$.

Hughes, D. E. (1962). The bacterial cytoplasmic membrane. J. gen. Microbiol. 29, 39.

Hunter, G. D. \& Godson, G. N. (1962). The final stages of protein synthesis and the role of lipids in the process. J. gen. Microbiol. 29, 65.

IKaws, M. (1963). Nature of the lipids of some lactic acid bacteria. J. Bact. 85, 772.

KANDLER, O. \& ZEHENDER, C. (1957). Über das Vorkommen von $\alpha, \epsilon$-Diaminopimelinsäure bei verschiedenen L-Phasentypen von Proteus vulgaris und bei den pleuropneumonieähnlichen Organismen. $Z$. Naturf. $12 \mathrm{~b}, 725$.

Lowry, O. H., Rosebrough, N. J., Farr, A. L. \& Randall, R. J. (1951). Protein measurement with the folin phenol reagent. J. biol. Chem. 193, 265.

Lucy, J. A. \& Dingle, J. T. (1962). Vitamin A and membrane systems. 2. Membrane stability and protein-vitamin A-lipid interactions. Biochem. J. 84, 76 P.

LYNN, R. J. \& SмIтh, P. F. (1957). Nucleic acid content of pleuropneumonia-like organisms from human sources. J. Bact. 74, 811.

Lynn, R. J. \& Smith, P. F. (1960). Chemical composition of PPLO. Ann. N.Y. Acad. Sci. 79, 493. 
MacFarlane, M. G. (1961). Composition of lipid from the protoplast membranes and whole cells of Micrococcus lysodeikticus. Biochem. J. 79, 4. P.

MacLeod, P. \& Brown, J. P. (1963). Fatty acid composition of lipids from Streptococcus cremoris and Streptococcus lactis var. maltigenes. J. Bact. 85, 1056.

Markovitz, A. \& Dorfman, A. (1962). Synthesis of capsular polysaccharide (hyaluronic acid) by protoplast membrane preparations of group A streptococcus. J. biol. Chem. 237, 273.

Mitchell, P. (1959). Structure and function in microorganisms. Biochem. Soc. Symp. 16, 73.

Morowitz, H. J. \& Cleverdon, R. C. (1959). An extreme example of the coding problem, avian PPLO 5969. Biochim. biophys. Acta, 34, 578.

Morowitz, H. J. \& Cleverdon, R. C. (1960). The irradiation of the pleuropneumonia-like organism A5969 with cobalt-60 gamma rays. Radiation Res. 13, 854.

Morowitz, H. J., Tountellotte, M. E., Guild, W. R., Castro, E., Woese, C. \& CheverDON, R. C. (1962). The chemical composition and sub-microscopic morphology of Mycoplasma gallisepticum, avian PPLO 5969. J. molec. Biol. 4, 93.

O'Leary, W. M. (1962). The fatty acids of bacteria. Bact. Rev. 26, 421.

Panos, C., Barkulis, S. S. \& Hayashi, J. A. (1959). Streptococcal L forms. II. Chemical composition. J. Bact. 78, 863.

Plackett, P. (1959). On the absence of 'mucocomplex' from Mycoplasma mycoides. Biochim. biophys. Acta, 35, 260.

Plackett, P. (1961). A polyglycerophosphate compound from Mycoplasma mycoides. Nature, Lond. 189, 125.

Razin, S. (1963). Structure, composition and properties of the PPLO cell envelope. Recent Progress in Microbiology, VIII, p. 526. Ed. by N. E. Gibbons. Toronto: University Press.

Razin, S. (1964). Osmotic Iysis of Mycoplasma. J. gen. Microbiol. 33, 471.

Razin, S. \& Argaman, M. (1961). Properties of the Mycoplasma (PPLO) cell envelope. Bull. Res. Coun. Israel, $9 \mathrm{E}, 121$.

Razin, S. \& Argaman, M. (1963). Lysis of Mycoplasma, bacterial protoplasts, spheroplasts and L-forms by various agents. J. gen. Microbiol. 30, 155.

RAzin, S. \& CoHEN, A. (1963). Nutritional requirements and metabolism of Mycoplasma laidlawii. J. gen. Microbiol. 30, 141.

Razin, S., Mrchmand, J. \& Shimshon, Z. (1964). The occurrence of Mycoplasma (pleuropneumonia-like organisms, PPLO) in the oral cavity of dentulous and edentulous subjects. J. dent. Res. (in the Press).

RAzin, S. \& Rottem, S. (1964). Fatty acid requirements of Mycoplasma laidlawii. J. gen. Microbiol. 33, 459.

RoBertson, J. D. (1959). The ultrastructure of cell membranes and their derivatives. Biochem. Soc. Symp. 16, 3.

Rothblat, G. H. \& Smrth, P. F. (1961). Nonsaponifiable lipids of representative pleuropneumonia-like organisms. J. Bact. 82, 479.

Schneider, W. C. (1945). Phosphorus compounds in animal tissues. I. Extraction and estimation of desoxypentose nucleic acid and of pentose nucleic acid. J. biol. Chem. $161,293$.

Schwan, H. P. \& Morowitz, H. J. (1962). Electrical properties of the membranes of the pleuropneumonia-like organism A 5969. Biophysical J. 2, 395.

Shockman, G. D., Kolb, J. J., BaKay, B., Conover, M. J. \& Toennies, G. (1963). Protoplast membrane of Streptococcus faecalis. J. Bact. 85, 168.

Smith, P. F., Lecce, J. G. \& LynN, R. J. (1954). A lipoprotein as a growth factor for certain pleuropneumonia-like organisms. J. Bact. 68, $62 \%$.

Smith, P. F. \& Rothblat, H. G. (1960). Incorporation of cholesterol by pleuropneumonialike organisms. J. Bact. 80, 842.

Smith, P. F. \& Rothblat, G. H. (1962). Comparison of lipid composition of pleuropneumonia-like and L-type organisms. J. Bact. 83, 500.

SurT, J. C. (1963). Ribonucleic acid in a 'membrane' fraction of Escherichia coli and its relation to cell-wall synthesis. J. Bact. 84, 1061. 
Umbreit, W. W., Burris, R. H. \& Stauffer, J. F. (1957). Manometric Techniques. Minneapolis: Burgess Publishing Co.

VAN ITERSon, W. \& Ruys, A. C. (1960). The fine structure of the Mycoplasmataceae (micro-organisms of the pleuropneumonia group PPLO). 1. Mycoplasma hominis, M. fermentans and M. salivarium. J. Ultrastr. Res. 3, 282.

Vendrely, R. \& Tulasne, R. (1953). Chemical constitution of the L-forms of bacteria. Nature, Lond. 171, 262.

Weibull, C. \& Bergström, L. (1958). The chemical nature of the cytoplasmic membrane and cell wall of Bacillus megaterium, strain M. Biochim. biophys. Acta, 30, 340.

Werbull, C., Beckman, H. \& Bergström, L. (1959). Localization of enzymes in Bacillus megaterium strain M. J. gen. Microbiol. 20, 519.

Wycoff, H. D. \& Parsons, J. (1957). Chromatographic microassay for cholesterol and cholesterol esters. Science, 125, 347.

Yudkin, M. D. (1962). Chemical studies of the protoplast membrane of Bacillus megaterium KM. Biochem. J. 82, 40 P. 